Migration Studies - Review of Polish Diaspora nr 3 (173)/2019, http://www.ejournals.eu/Studia-Migracyjne/

10.4467/25444972SMPP.19.031.11073

\title{
Rethinking Agency, Rethinking Assumptions of the New Social History of Immigration of the Late Twentieth Century
}

\author{
DAVID A. GERBER ${ }^{1}$ \\ University at Buffalo (SUNY), Emeritus
}

\begin{abstract}
In the last decades of the twentieth century, the concept of agency - i.e., purposeful self-determination based on calculated choice - enjoyed a hegemonic position in the literature of the social history of European immigration to the United States. The original inspiration for this development in immigration historiography was the path breaking 1964 essay by essay by Rudolph Vecoli challenging the classic work on Oscar Handlin, The Uprooted (1951), which saw immigration as a jarring experience of alienation and confusion that left immigrants defensive and poorly adjusted in their new American homes. This essay reexamines the conflict of views associated with Vecoli's challenge to Handlin in two contexts. One is the conceptual and empirical foundations of immigration historiography, and the second is the origin and early development of the New Social History, in British and American labor history and in the history of African American slavery and in Western neo-Marxism thought, which sought a humanist alternative to Communist ideology. The essay seeks critical engagement with agency, and advances the view that we should open ourselves once more to seeking guidance in Handlin's interpretive understandings, which also suggests a reevaluation of the contributions of Thomas and Znaniecki's The Polish Peasant in Europe and America, the now century-old source of Handlin's views.
\end{abstract}

Keywords: agency; immigration; transnational; institutionalization; peasants; ideal type; the New Social History; The Uprooted; The Polish Peasant in Europe and America; cultural baggage

\section{Immigrants and Psychiatric Confinement}

In 1880, when immigrants were $14 \%$ of the population of the United States, they comprised $40 \%$ of the population of those who had been committed to psychiatric institutions, a datum that intensified a decades-long debate about the quality of migrants

\footnotetext{
1 Contact: dagerber@buffalo.edu
} 
to America and the presumed excessive liberality of immigration law. ${ }^{2}$ This figure comports very closely with the extent of the foreign-born (36\%) thirty years later at a New York State institution for the insane, Willard State Hospital, which collected people with diagnosed psychological illnesses from all over the state, but mostly at that time from the heavily immigrant population centers in the demographically dominant New York City metropolitan area. I became familiar with Willard and its significant number of foreign-born residents as a consequence of a unique museum exhibit, The Lives They Left Behind, organized by the New York State Museum. The exhibit featured the abandoned trunks and luggage, some dating back over a century, of institutionalized residents found in the attic of Willard after it ceased operation in the 1995. Of the nearly 500 trunks and suitcases, the museum curators chose to analyze the contents of 27 and to feature for public display and analysis those belonging to 10 deceased individuals, all of them committed to the institution from approximately 1920 to 1960 . Their biographies were profiled alongside these artifactual remains. What struck me immediately in looking at the exhibit was that 6 of them were immigrants and 1 was a refugee. ${ }^{3}$

The book done in conjunction with the exhibit suggested the reason for the disproportionate representation of international migrants in a variety of ways. One seems to have been the influence on the curators of the compelling, complex stories represented by these individuals who journeyed from their homes in Europe, or in one case in the Philippines and another from Egypt, to America in search of a better or at least a different life. Yet ended up instead in most instances lifelong residents in a psychiatric hospital, under the custodial care of the state. A second reason is material: the exhibit curators discovered that the foreign-born residents left the fullest collection of artifacts - an extensive and diverse range of belongings, including adult and infant clothing, books, letters and postcards, photographs, and household goods, which the authors speculated resulted from a telling fact. In contrast to American residents, there was often no one dependable enough or sufficiently accessible to them, geographically or in familiar terms, to take care of their property, while they were resident at the hospital. The disposition of these artifacts was rooted in the social profile of the foreign-born residents. In contrast to the residents from the institution's Upstate New York catchment area, which was more Anglo-American, residents from the New York City area were not only likely to be foreign-born, but single and disconnected from both communities and social

2 Gerald N. Grob, Mental IIIness and American Society, 1875-1940 (Princeton: Princeton University Press, 1983), p. 8. Also, see, for the earlier period, Grob, Mental Institutions in America: Social Policy to 1875 (New York: The Free Press, 1973), Chapter 6; and David J. Rothman, Discovery of the Asylum: Social Order and Disorder in the New Republic (Boston: Little, Brown and Company, 1971, second edition), pp. 283-287.

3 Darby Penney and Peter Stastny, The Lives They Left Behind: Suitcases from A State Hospital Attic (New York: Bellevue Literary Press, 2008), pp. 38-40. 
networks. They lacked anyone reliable enough to take care of their property while they were at Willard. ${ }^{4}$

The incidence of psychiatric illness among immigrants is a fraught and controversial subject, beginning with the basic question of how reliable the data may be on illness, institutionalization, and nativity themselves, all subjects beyond the scope of this essay. Here we shall analyze how American social historians in recent decades have conceived of immigrants, and what high rates of confinement to institutions for those with psychological illnesses may tell us about the interpretive frameworks of social historians of international migration to the United States.

First, however, we might examine briefly what those high rates of institutionalization do generally suggest about immigrants, which may serve as a backdrop for rethinking the dominant trend in the historiography. My thinking on this is guided by the contemporary critique of historical psychiatric practice and of institutionalization. ${ }^{5}$ That critique is founded on the understanding that while there are certainly individuals who suffer from severe, organic and sometimes heritable psychological illness, the most significant feature of which is a capacity to injure themselves or others, chronic sickness of the mind must be differentiated from acute, shorter-term problems in living. These commonly manifest themselves in confusion, depression, anxiety, anger or obsessive and compulsive behaviors, problems that are worsened in large numbers of people by self-medication with alcohol and drugs. ${ }^{6}$ Immigrants experience many problems in living that come with the challenges of the migration and resettlement project on which they have embarked. In his definitive study of immigrant health, Alan Kraut, whose interests lay elsewhere - in physical health and in public policy debates prompted by competing eugenic/nativist and environmental explanations of illness - briefly acknowledges the role of stress as an all-consuming issue for some immigrants that undermined both their physical health and their morale. Kraut is one of the few American immigration social historians who has ventured that far in broaching the subject in the larger context of immigrant health. ${ }^{7}$ Far more interest

4 Penney and Stastny, The Lives They Left Behind, pp. 14-18, 39, 40.

${ }^{5}$ A convenient, incisive review of the trends in this literature can be found at http://h.net.org/reviews/ showpdf.php?id=50718, Michael Rembis, review of Greg Eghigian, ed., The Routledge History of Madness and Mental Health (New York: Routledge, 2017).

${ }^{6}$ My thinking about assumptions on mental illnesses and the clinical practice of psychiatry is based on the critique of historical practices; hence attention to history is explicit in most of the thoughtful reformist literature. See, Robert Whitaker, Mad in America: Bad Science, Bad Medicine, and the Enduring Mistreatment of the Mentally III (New York: Basic Books, 2010, revised edition); Paula J. Caplan, They Say You're Crazy: How the World's Most Powerful Psychiatrists Decide Who's Normal (Boston: Addison-Wesley, 1995); National Council on Disability, From Privileges to Rights: People with Psychiatric Disabilities Speak for Themselves (Washington, D.C.: National Council on Disability, 2002); Marius Romme and Sandra Escher, Accepting Voices (London: Mind, 1993).

7 Alan Kraut, Silent Travelers: Germs, Genes, and the 'Immigrant Menace' (New York: Basic Books, 1994), pp. 39-40, 163-164. Recent scholarship on British colonial policy, psychological illness, and imperial migrations is another exception; see, Catherine Coleborne, Insanity, Identity, and Empire: Immigrants 
has been found among ethnic novelists, from such early twentieth century writers Ole Rølvaag, James T. Farrell, Henry Roth, and Pietro DiDonato to the mid-twentieth century novelists Bernard Malamud and Mario Puzo. ${ }^{8}$ Novelists' interests in intimate and personal relations and in the interior lives of their subjects, who were often based on immigrants they had known or known of, led to realistic portraits of people in the midst of daily challenges, i.e., problems in living, that ultimately expressed themselves in psychological illnesses. Immigration historians have had far less interest in the interior lives of their subjects and in intimate and personal relations. They study groups much more often than individuals, and infrequently examine personal and intimate relations.

While such problems in living can be incapacitating, they do not necessarily involve interpersonal violence, self-harm or a long-term dissolution of personality or loss of motivation. But if an individual acts out symptoms in public, and is perceived as a public nuisance or threat, and is without personal resources, such as communal support networks in family or friends, and the material resources to seek private care, it is been common historically for those suffering from problems in living to end up in public institutions, all too often for a lifetime. Public psychiatric hospitals, like institutions for the developmentally disabled, have often been dumping grounds for friendless and powerless children and adults who run into such ordinary difficulties. In consequence, they became wards of the state, which in partnership with the police, law courts and medical profession, has had the ultimate power to relieve people of their freedom and place them in custodial care that ultimately approached incarceration and carried with it a virtual life sentence. That a therapeutic was involved cannot be denied, especially in the early history of psychiatric institutionalization in the United States, when the model of care was conscientiously humane and cures, based on work, recreation, and healthful living, were seriously sought. But with the physical expansion of individual institutions and of the patient populations within them came in the twentieth century in the United States a widespread incidence of abuse and indifference, which manifested itself in the use of neuroleptic drugs

and Institutional Confinement in Australia and New Zealand, 1873-1920 (Manchester: Manchester University Press, 2015); Angela McCarthy and Catherine Coleborne, editors, Migration, Ethnicity, and Mental Health: International Perspectives, 1840-2010 (Abingdon: Routledge, 2011), and most recently, Marjory Harper, ed., Migration and Mental Health: Past and Present (London: Palgrave Macmillan, 2016). All but one of the seven place-specific essays in Harper's collection of essays on the subject concerns the British Empire and Commonwealth. For a general perspective, Jonathan Andrews, "Travel and Mental Disorder, c. 1700-1900," in Richard Wrigley and George Revill, eds., Pathologies of Travel (Amsterdam: Brill Rodopi, 2000), pp.25-88.

8 Ole Rølvaag, Giants in the Earth (New York: Harper and Brothers, 1927); Henry Roth, Call It Sleep (New York: Cooper Square Publishers, 1934); James T. Farrell, Studs Lonigan: The Trilogy (New York: the Modern Library, 1938) and especially, volume three of the trilogy, Judgment Day (1935); Pietro DiDonato, Christ in Concrete (Indianapolis: Bobbs-Merrill, 1939); Bernard Malamud, The Assistant (New York: Farrar, 


\section{SM̂PP}

and physical restraints throughout the patient population, in surgical lobotomies, and in the collapse of patient living conditions. ${ }^{9}$

The circumstances of migration and the related circumstances of resettlement may have overdetermined the high incidence of institutionalization revealed in the fragmentary data noted at the beginning of this essay. Immigration and in relation, cultural difference seem to have made psychologically vulnerable individuals more vulnerable, because it put them under significant stress. Add to the effects of movement and resettlement, the impact of racist and nativist laws and social practices that purposely disrupt life at the most basic levels of existence, such as family and marriage, in the case of non-white migrant and refugee peoples, and the possibilities are certainly overdetermined for stress.

\section{Historiography: Agency and Its Limitations}

Having established that background, the essay turns to what the disproportionate incidence of immigrants among the institutionalized may suggest to us about a major direction taken in the last four or five decades in the social history of immigration historiography - the discovery in the late twentieth century of agency, and what that direction tells us about ourselves as practitioners of historical interpretation. I want to interrogate, as a sort of historiographical archeology, both the wholesale rejection of Oscar Handlin's conceptualization of immigration and resettlement as an experience of disorganization and alienation, and the embrace of the alternative conceptual model associated with Rudolph Vecoli's iconic 1964 deconstruction of The Uprooted. Vecoli's critique of The Uprooted is based on immigrant agency, the immigrants' capacities to plan for themselves - a kind of creativity in daily living that is rooted in tradition and culture. ${ }^{10} \mathrm{I}$ recognize that the former purpose at this point in time certainly is something of a fool's errand: nothing seems to be more dead and buried than The Uprooted, which has served for over half-century as a statement of what historians should be rejecting and arguing against. I believe, in contrast, that there is still much to be learned from The Uprooted, and that, for example, high rates of im-

${ }^{9}$ Nancy Tomes, The Art of Asylum-Keeping: Thomas Story Kirkbride and the Origins of American Psychiatry (Philadelphia: University of Pennsylvania Press, 1994); David L. Gollaher, A Voice for the Mad: The Life of Dorothea Dix (New York: Free Press, 1994); Albert Deutsch, The Shame of the States (New York: Harcourt, Brace, 1948); Penney and Stastny, The Lives They Left Behind, pp.102-113.

${ }^{10}$ Rudolph Vecoli, Contadini in Chicago: A Critique of The Uprooted," Journal of American History, 51, \#3 (December, 1964), 404-17. Though Vecoli did not have Handlin's second edition of The Uprooted, but rather only the 1951 first edition, I cite the second edition (Boston: Little Brown and Company, 1973) here, because there is a new chapter added by the author that contains additional methodological, bibliographic, and autobiographical contextualizations of Handlin's interpretive goals and analytical strategy. 
migrant institutionalization for psychological illnesses suggest the need for a critical rereading of Handlin's work. ${ }^{11}$

The assault on Handlin's deeply pessimistic, empathic portrait of the immigrant as an uprooted and alienated peasant has come from two general directions. Most recently, his total neglect of race in the case of non-European immigrants from Asia and the Western Hemisphere and his virtual silence on gender - his subject is always a he - have made him irrelevant especially to younger historians, for whom racialization and gender are the current agenda of the field. Handlin appears as the archetypical academic patriarch, governing the kingdom of unreflective white men's, Euro-American immigration history that is part romance and part unreflective, insidious and racialist ideology. He and others analyzing the 35,000,000 European immigrants who came to the United States in the century after 1820 are casually dismissed in a recent broad-scale synthesis as "Ellis Island historians," whose sights never get very far from their own European genealogies or from New York harbor. ${ }^{12}$

The longer-standing rejection of The Uprooted, the second direction, has been founded upon the attraction of Vecoli's agentic, purposeful migrant (also posited as a he), strategizing opportunity on an international stage to maximize individual gain and to take power over his life. Vecoli's immigrant's aspirations developed within the terms of an existing communal and familial worldview crafted in peasant communes of the Old Country. But, though the aspirations may remain the same, they are tactically subject to revision as circumstances suggest. This immigrant is a canny traditionalist, yet somehow a global citizen, transnational before we invented the word. He was able to bend emerging capitalist labor markets in his favor to accomplish his goals. Vecoli urged historians to reject Weberian ideal type analysis of peasants across geographical and cultural space as a class that Handlin adopted, ${ }^{13}$

11 I have written two short essays in the service of revitalizing interest in Handlin's legacy for immigration history and an understanding of meanings of American experience. See, David A. Gerber, "What Did Oscar Handlin Mean in the Opening Sentences of The Uprooted?," Reviews in American History, 41, n. 1 (March, 2013), 1-11; and, for a special issue of the Journal of American Ethnic History,32, n.3 (Spring, 2013), "Forum of the Legacy of Oscar Handlin," with contributions by John Bukowczyk, Tyler Anbinder, Hasia Diner, Alan M. Kraut, Mae M. Ngai, Touré F. Reed, and Lorrin Thomas, done shortly after Handlin's death, see, David A. Gerber, "The Uprooted Would Never Have Been Written If Oscar Handlin Had Taken His Own, Latter-Day Advice," 68-77.

12 Paul Spickard, Almost All Aliens: Immigration, Race, and Colonialism in American History and Identity (New York: Taylor and Francis, 2007), p.6 for the reference to Handlin's legacy and the indictment of his casual inattention to non-European immigrants. More balanced and comprehensive efforts than Spickard's at interpreting Handlin and his legacy are to be found in the essays in the special issue of the Journal of American Ethnic History, 32, n. 3 (Spring, 2013), 7-67; and in an article by Handlin's distinguished former Ph.D. student, David Rothman,"The Uprooted: Thirty Years Later," Reviews in American History, 10, n.3 (September, 1982), 311-319.

13 In the second edition, Handlin briefly defended this type of analysis as rendering ultimately what all migratory peasants, and indeed all migratory peoples, have in common after cultural, economic, and 


\section{SM̂PP}

and develop instead a culturally and geographically specific lens fitted, in his case, to the southern Italy that he knew so well. In the latter advice, Vecoli was certainly correct: ideal type analysis has proven viable as a way of generating sharper analytical questions, but there is an obvious hazard in taking the ideal type as fact, applicable to anyone in particular. Ideal types are imagined mostly by logic, not by systematic empirical investigation. But the conceptual model, peasant agency, Vecoli asked his readers to embrace has brought with it its own interpretive difficulties.

In 1964 Vecoli was one of the first historians in North America to advance this sort of framework for understanding the previously unimagined resources the poor and relatively powerless brought into the struggle for dignity and survival. His work actually preceded by several years the widespread and explicit seizing upon agency as a conceptual model among social historians. At that time Vecoli did not use the word agency, which then was not in the American historian's vocabulary. That usage would come when stronger analytical threads in social history were sown by labor historians and historians of African American slavery. They were ultimately inspired by the English neo-Marxist E.P. Thompson, an enormously influential figure in late twentieth century Anglo-American historical studies. ${ }^{14}$ Thompson sparked the path breaking creativity of the American Herbert Gutman, who made significant contributions to both labor and slavery historiographies through the assumption in both cases of the cultural standpoints of immigrant proletarians and African American slaves.

Agency soon became, as Guttman's doctoral student Walter Johnson stated in a skeptical 2003 retrospect on its contributions to the African American slavery literature, "the master trope" of the New Social History. ${ }^{15}$ Its ideological legitimacy was heavily founded on a moralized psychological insight that channeled the existentialist position of Jean Paul Sartre: beyond understanding what is done to people must be a still larger goal, understanding what people do with what is done to them. ${ }^{16}$ This formulation was attractive, too, in the context of the Western New Left and Neo-Marxist politics of the time. New Left and Neo-Marxist historians in the West sought to find in history precedents for a progressive politics opposed to capitalist power and cultural hegemony that was not rooted in the official Marxism of the Soviet Union, an ossified, authoritarian regime with totalitarian aspirations. Emotionally, furthermore, agency carried a distinctly feel-good message: it reclaimed the humanity of those who had been denied subjectivity in the historical narratives in which, as unnamed and unanalyzed shadows, they had once appeared. Non-elite people were given identity, and

social differences are factored and the experience of uprooting amidst "unexpected adjustments" in "unstable new environments" is analyzed; Handlin, The Uprooted, pp. 304- 306. The discussion, however, lacks depth, definitional clarity and analytical precision.

14 E.P. Thompson, The Making of the English Working Class (London: Victor Gollancz Ltd., 1963).

${ }^{15}$ Walter Johnson, "On Agency," Journal of Social History, 37, n.1 (Autumn, 2003), 113.

16 Herbert G. Gutman, "Labor History and the 'Sartre Question'," reprinted in Power and Culture: Essays on the American Working Class, Ira Berlin, ed., (New York: Pantheon, 1987), 326-28. 
increasingly proven to be three-dimensional and self-directing. They were in Thompson's memorable remark rescued, from "the enormous condescension of posterity." ${ }^{17}$

Agency unleashed tremendous scholarly creativity. Following the insights of Gutman into slave cultural resistance to the dehumanization of bondage and into the ways in which Old World communal traditions might be the foundation of worker resistance to proletarianization in the new mass production factories in industrial cities such as Paterson, New Jersey or Chicago, younger historians focused on bottom up analyses. These brought the neglected and poorly analyzed men, and very soon women, and peoples and groups into the center of social and political historical narratives. ${ }^{18}$

But problems always lurked below the surface of the New Social History. To contend for the humanity of those who are human, as the Nobel laureate Tony Morrison memorably observes in the context of imaginative literature, is to continue at a fundamental level to let the racists and nativists who have argued to the contrary form the agenda of History. It is also to argue, as Johnson states powerfully, that self-determination and choice, the fundamental criteria of Western liberal ideology, are the ultimate measure of being human, and to privilege the development of forms of politics and social behavior generally that arise out of self-determination and choice, reproducing, Johnson continues, "the liberal agent as the universal subject of history." 19 One problem, of course, is that self-determination and choice may not always be possible, and people may need to act contrary to what would seem to be their path to a politics of liberation. But that is itself to argue within the framework of liberal ideology, for people might see the world and themselves in very different ways that are at odds with what is conventionally deemed political in Western terms. How to live within such oppressive circumstances as plantation slavery may very well be understood quite differently within the mental frameworks of different peoples.

In Vecoli's conceptualization of immigrant social history we see this logic at work. Vecoli's southern Italian immigrants in his famous essay are not only not Handlin's alienated, disorganized peasants, but they are also workers, with a proto-politics, who take capitalism on their own terms and resist its logic, just as they resist the Americanizing logic of nativists. The foundation of their resistance, their choices and the logic

17 Thompson, The Making of the English Working Class, p. 12. An equally alluring formulation was the anthropologist Eric Wolf's "the people without history," Europe and the People without History (Berkeley: University of California Press, 1982), referring to the non-European peoples brought into trading and labor relationships with dominant European powers during the long course of modernization and globalization. In those relationships, the European rural and urban proletariat had a liminal position, at once relatively benefited through a slowly improving standard of living but simultaneously oppressed and exploited. Wolf did not intend the phrase to describe the European underclasses, but it speaks nonetheless to their unstated position in the understanding of the transformation of society and the world itself, as they themselves understood and reacted to it, that Thompson made his project as an historian of the English working class.

${ }^{18}$ See the collection of Gutman's essays, Power and Culture, Berlin, ed., and Gutman's masterwork, The Black Family in Slavery and Freedom, 1750-1925 (New York: Pantheon, 1976).

19 Johnson, "On Agency," 117-118. 


\section{SM̂PP}

behind their self-determination, is, as it would be for Gutman, culture. But culture for Vecoli in his 1964 essay is reified. It is a unified block that resembles a thing, or as it would come to be known for a time in the historical immigration literature, baggage, from which resources are opportunistically unpacked when required in the exercise of self-determination and in pursuit of aspirations that are also to be found packed away in the same baggage.

Culture is not a thing, however, but rather a process that guides individuals imperfectly through life. Culture frames and channels behavior, but it does not decide behavior, which is the result of a much more complex and situationally specific process negotiated by individuals. ${ }^{20}$ Vecoli's sources in the 1964 essay, in contrast to Handlin's in The Uprooted, are telling in this regard. In his text, Handlin quotes from immigrant letters and other sources of contemporary first person testimony, which capture a range of individual resolves, longings, hopes, and fears. ${ }^{21}$ In contrast, Vecoli heavily cites what is said about the ways the southern Italian peasant immigrants in Chicago behave and what they think by University of Chicago sociologists and other American social scientists, social workers and social work agencies, and bourgeois Italian and Italian American intellectuals and professionals such as newspaper editors, and in Italian and American government reports. ${ }^{22}$ These sources represent elite individuals and institutions that evaluated the people they sought to understand from a cultural position outside those people, though at their most perceptive, as in the case of Jane Addams, they were conscious of that distance and troubled by the difficulties it presented. They were driven in the nature of their imaginative and intellectual purposes toward ethnic and national generalizations in their efforts to organize their thinking about what was unfamiliar. Moreover, the same individuals and institutions, for better or for the worse, ultimately sought to understand the southern Italian peasant immigrants for purposes of manipulation - to change their thinking and behavior.

${ }^{20}$ My view of culture, like that of many contemporary researchers who employ the concept, has been influenced by Clifford Geertz's symbolic anthropology, The Interpretation of Culture; Selected Essays (New York: Basic Books, 1973). Geertz saw culture as a shared process of meaning-making, but though brilliant at analyzing that meaning-making and the symbolic world created in its behalf, he was less concerned with the point I am explicitly referencing here: the bridge between the external symbols that for him did the work of culture, and the dispositions of individuals.

${ }^{21}$ It has always been a source of frustration for readers that Handlin did not choose to footnote his sources and to attribute the often dramatic and evocative quotations he quotes to their sources. The Second Edition does contain a bibliographic essay discussing secondary historical, social science, and novelistic sources and an explanation in that connection of The Uprooted's conceptualization, but it continues to leave the quotations without attribution. Neither edition has footnotes.

22 Vecoli's essay contains 58 footnotes, citing 109 works, some once and others multiple times. These citations represent: The Uprooted (18); published ethnography (Social Science) (17); published ethnography and reform-oriented publications (Social Work) (12); unpublished doctoral dissertations (including Vecoli's 1963 dissertation), Master's theses, and student papers (12); government reports (American) (10); the Italian American press (7); the American press (4); Italian American organizational publications and published proceedings (3); Roman Catholic Church publications (3); published immigration studies (2); and miscellaneous published historical, tourist, and popular ethnography (21). 
Vecoli may have restored the presence and asserted the agency in historical literature of the southern Italian peasant immigrants. But he did so in his landmark essay without letting many of them speak for themselves and without offering a view of the variations and differences among them. What he says about the emerging ethnic group, therefore, is not sustained with reference to the behavior of any individuals about whom he was presumably writing. In doing so, he nonetheless assisted in laying down the interpretive foundations of our literature. While Vecoli himself did not romanticize the immigrants, that literature has continued over the decades to treat agency as a matter of faith - that is, what we will find, if we conscientiously commit ourselves to finding it, is a life affirming story that dignifies history's poor and oppressed. ${ }^{23}$

Moreover, it is implicit that we will somehow find in the individual, should we make the effort to inquire, the characteristics we believe we have found in the group, though logically shouldn't our thought process be the other way around - the portrait of the group being comprised of individual examples? These assumptions may be found in conclusions drawn from evidence of group attainments. If we find evidence of successful ethnic communal endeavors (for example, building a church, or creating a mutual benefit society, or orchestrating a public protest demonstration), it must mean that the individuals who compromise the group are, as individuals, enterprising, creative, and pro-active. If we do not seek them out as individuals, however, how do we know this?

A problem is that in order to write that positive story of communal attainment one must sweep away what doesn't support it, no matter how insistently that contradictory evidence asserts itself. High rates of immigrant commitment to psychiatric hospitals are a dramatic example of that erasure. Those high rates stand out, for me, not because the immigrants were insane. Nor do they stand out because the immigrants were what the racists, nativists, and xenophobes said about them - and, in fact continue, to say about them - a danger to the United States whose presence was fostered by lazy humanitarian thinking and too liberal or unenforced immigration laws. They stand out instead, because they suggest the lapses and failings in our ability to analyze and interpret the immigrants and the lives they made or failed to make for themselves. In correcting that deletion, I find Handlin, for all of the many limitations of The Uprooted, to be suggestive in generating the beginnings of a realist perspective. In her investigations of immigrant psychological illness within the British Empire and later

23 Doubts about the good-news quality of agency-inspired scholarship were present at the time of its almost absolute dominance. In a guardedly laudatory review of Gutman's masterwork on the African American slave family, Dan T. Carter expressed caution about accepting Gutman's positivity, writing that Gutman "attempts to put (from his own interpretive perspective) "the 'best' possible face on the evidence" and often argues less about the ambiguous nature of his evidence than about the perceived errors in the arguments of previous historians. "Anyone who is familiar with the relevant sources knows that there are other and far more depressing facets to the culture of the derived...;" "Moonlight, Magnolias, and Collard Greens: Black History and the New Romanticism," Reviews in American History, 5, n. 2 


\section{SM̂PP}

Commonwealth, Marjorie Harper has recently suggested we revisit Handlin for guidance on this particular subject. The Uprooted may be of even larger value as a general corrective to one-dimensional portrayals of immigrant agency. ${ }^{24}$

As most social historians of immigration are aware (for it is one of the creation myths of American immigration historiography), Handlin appropriated and poetically rendered William I. Thomas and Florian Znaniecki's modernization/ disorganization cycle, which was developed in The Polish Peasant in Europe and America25, to explain the inner world of the European peasant immigrant, and to build on the grim, pessimistic interpretation found in his Boston's Immigrants, published a decade before The Uprooted. ${ }^{26}$ Like Thomas and Znaniecki's Polish immigrants, Handlin's immigrants in both of these books are swept up in a tidal wave of irresistible historical change. It destroys an ancient peasant way of life that could be cruel and exacting, but was predictable and explainable within the framework of a tradition-bound, religiously framed peasant culture, central to which were the rhythms of nature and the ritual calendar of the church. The disorganization prompted by industrialization leaves them at the mercy of the commercialization of agriculture, proletarianization, and the pull of the slums of the emerging industrial cities. Immigration for Handlin is a reflexive, defensive response to the collapse of peasant agriculture, not one item among several on a checklist of possibilities and on an agenda for propelling oneself into the future. His peasants are equally without effective resources for dealing with the American urban, industrial environment into which the logic of international shipping and job markets direct them. Though not without bitter irony, Handlin redeems the immigrants' hopes by laying on to their chaotic lives that they have won a better future for their children, from whom they are deeply alienated by history and experience, and that they have liberated themselves from a shackles of the tradition, which in the midst of the existential crisis of their lives they are hardly in any position to appreciate.

Vecoli is right in his general criticism of the extent to which this picture is greatly exaggerated. Both the portrayal of the old way of life in the European countryside and the new way of life in the United States are overly generalized to accomplish that poetic rendering of Thomas and Znaniecki, one which was ultimately perhaps as autobiographical in inspiration, as Handlin himself was eventually to suggest in a later edition of the book, as it was empirical. ${ }^{27}$ But the impasse between the two conceptual

${ }^{24}$ Marjory Harper, "Ethnicities and Environments: Perceptions of Alienation and Mental Illness among Scottish and Scandinavian Settlers in North America, c.1870-1914," in Migration and Mental Health, Harper, ed., p.121.

${ }^{25}$ Willian I. Thomas and Florian Znaniecki, The Polish Peasant in Europe and America, volumes I and II (Chicago: University Chicago Press, 1918), and volumes III, IV, and V (Boston: The Badger Press, 1919, 1920).

${ }^{26}$ Oscar Handlin, Boston's Immigrants 1790-1880 (Cambridge: Belknap Press of Harvard University Press, 1941).

27 Readers of the first edition of The Uprooted may have wondered whether the chapter "Promises," (pp. 268-273), a dialogue between father and son on the existential dilemmas posed by immigration 
models should not simply be allowed to stand in a position that gives each historian his due, and, in effect, declares that the argument comes inconclusively to a draw.

Under the authority of agency, we have come to appreciate the extent to which immigration and resettlement have been structured by family, communal, and ethnic networks and ultimately by ethnic religious and other social institutions, which have countered the disorganization that Handlin found prevalent. But American immigration historians still have much less understanding, to my mind, of whether such networks were, in fact, universally present and able to sustain themselves over time in the case of individuals. Nor do we have a sense of the universality of the hold of ethnic social institutions on the immigrants. It is easier to analyze the immigrants as parts of vital, stable and creative communities of their own ongoing creation than to see them as isolated individuals outside of them. But it is hardly unrealistic to imagine the absence of such networks in the case of the many international migrants who arrive alone and friendless, or were engaged in networks that broke down, because of interpersonal disagreements, illness, death or poverty. Moreover, it is not difficult to imagine the resistance of individuals to giving over their time to even the most sustaining communities and institutions, when they are up against the need to work long hours, when work is unpredictably available, and when they are attempting to save their wages to support family in their homelands or to finance the forging of migration chains linking both the old and new worlds.

In the absence of such understandings, we lack a significant perspective on how many immigrants were able to overcome or not overcome the substantial sources of stress that were an inevitable part, on multiple personal and social levels, of the challenging project of migration and resettlement. Certainly in the immigrants' letters I read for many years in preparation to write my study of the private relations embedded in immigrant writing, frustration, loneliness, self-doubt, loss of confidence in the future, and fraying affectional ties appear routinely alongside the gains and triumphs that served to redeem immigration for individuals. Our literature of the social history of immigration, however, has prepared us to anticipate the latter, but to bracket the former. Until we put the two terms of experience in balance, however, we cannot understand immigrants or immigration and resettlement. 